\title{
THE EXAMINATION OF GATHERING POINTS' CAPACITY REGARDING MOBILITY AND ACCESSIBILITY: CASE OF BAYRAKLI DISTRICT
}

\author{
N. S. Partigöçç, ${ }^{1,}$ H. E. Erdin ${ }^{2}$, H. Zengin Çelik ${ }^{2}$, M. B. Sılaydın Aydın ${ }^{2}$ \\ ${ }^{1}$ Department of City and Regional Planning, Pamukkale University, 20160 Kınıklı Denizli, Turkey - npartigoc@ pau.edu.tr \\ ${ }^{2}$ Department of City and Regional Planning, Dokuz Eylul University, 35160 Tinaztepe Izmir, Turkey - evren.erdin@ deu.edu.tr, \\ hayat.zengin@deu.edu.tr, burcu.silaydin@deu.edu.tr
}

KEY WORDS: Disaster, Social infrastructure areas, Gathering points, Accessibility, Geographical Information Systems (GIS)

\begin{abstract}
:
The concept of accessibility that bases on continuing the flow of people, goods and services uninterruptedly is discussed as "maximum contact by minimum facility". This concept which is related with the distance has been evaluated various criteria such as physical, economic, perceptual, temporal, etc. Several assignations (optimum location, minimum distance, best distribution method, etc.) have revealed the importance of gathering points in terms of proceeding the disaster management properly. The origin point of linking "accessibility" and "transportation network" is the mobility which reveals as accessing people to adequate gathering points and services in the shortest time. These gathering points which are determined due to the specific criteria and also referred to the social infrastructure areas have a vital importance when any disaster or emergencies occur; so the site selection, availability and accessibility of these areas become extremely significant. The aim of this study is to examine the accessibility of gathering points in Bayrakli district located in Izmir city by taking minimum standards and also some recommendations into consideration. The spatial analyses based on current and potential gathering points are carried out via ArcMap software. The current and potential gathering points in Bayrakli district are examined in terms of accessibility their capacity for each neighbourhood due to their spatial distribution. According to the results, each gathering points in neighbourhoods cannot be accessible in the shortest duration by walking and also the current urban pattern affects the capacity parameter regarding the accessibility and mobility significantly.
\end{abstract}

\section{INTRODUCTION}

The legislation and literature related the disaster management reveals that existing settlements have a significant inadequacy of areas which can be used in an emergency case or disaster. These areas serve many critical purposes in urban area such as gathering points and temporary shelters, storage areas, logistics centres, evacuation corridors, distributing supplies to survivors during and after disasters, etc (Erdin et al, 2017).

It is appointed that certain urban facilities (parks, playground areas, open and green areas, recreation areas, etc.) are fulfilled in the built urban environment to provide necessary areas in the disaster management. Among these types of facilities, urban gaps, public areas and also open green areas are recently more important in terms of gathering points and temporary sheltering in cities. According to the overall tendency, citizens need more easily accessible and also secured open areas when an earthquake occurs and they panic in the first stage of disaster. In this general case, the closest open areas, streets and roads become the first preference by citizens. Roads and streets can be determined as a tool guiding citizens to gathering points and being enable to access these areas.

The gathering points can be defined as generally public open and green areas which are quickly and regularly accessed, easily realized and also have sufficient size. These points will provide not only secured areas to survive but also crucial advantages to survivors in terms of understanding their situation, receiving help, and hearing from their relatives and reaching essential information related the disaster. The gathering points are so critical and vital in the first 12 and 24 hours to be inquired about the event (Maral et al, 2015). In fact, it is possible to evaluate the gathering areas as the first step of spatial organization in the disaster management. So, the alternative usage of existing open and green areas as gathering points and the querying of their adequacy should be taken into consideration in terms of the accessibility and capacity.

The purpose of this study is to examine the accessibility of gathering points in Bayrakli district located in Izmir city by taking minimum standards and also some recommendations into consideration. The spatial analyses based on current and potential gathering points are carried out via ArcMap software. The current and potential gathering points in Bayrakli district are examined in terms of accessibility and capacity for each neighbourhood due to their spatial distribution.

In the study, querying the capacity of gathering points referred as open and green areas and examining the accessibility of these areas easily in terms of the distance or duration are critical. Moreover, the assessment of the capacity and adequacy which is being carried out today over the area size will be made in the light of the findings. According to the results, it can be said that all evaluations related gathering points in urban area are insufficient when they are carried out due to only the area size and population.

\footnotetext{
* Corresponding author
} 


\section{THE ADEQUECY AND ACCESSIBILITY OF GATHERING POINTS}

The phenomenon of accessibility has a critical role about the spatial organization and daily life in urban areas with the scope of the site selection of urban land uses, their sizes and availability, the relations between these land uses, etc. The accessibility is generally associated with the distance parameter and also is determined due to the physical, temporal and perceptual measurements (Erdem et al., 2017). On the other hand, the concept of accessibility in the disaster management varies in terms of its context based on the physical and spatial accessibility. Konstantinidou et al. (2014) define the transportation networks as the critical lifelines because of their functions and characteristics in the disaster management. These functions can be mentioned as gathering points and temporary shelters after disasters, evacuation of transportation system, emergency intervention and rescue operations (Konstantinidou et al., 2014). Especially in the emergency period when any disaster occurs, the accessibility of citizens to certain gathering points is vital to minimize the loss of life and property in disasters.

The concept of accessibility in the disaster management has different context for two different groups such as service providers (coordination units, service groups, disaster response teams) and service receivers (citizens and survivors) (Erdem et al., 2017). It is definitely known that citizens generally need safe conditions and areas in the city including roads, gathering points, evacuation areas, temporary shelters, etc. The disaster response teams aim to provide these safe conditions and areas. Therefore, the accessibility of various areas related the disaster management is crucial. As examples of these areas, there exist any disaster and danger points, deployment areas, logistics centres and warehouses, field hospitals, mobile cooking places, alternative patient care areas, areas for tent cities, container areas, public buildings and sports facilities, temporary shelters, aid and tent storage, etc. In other words, the principal aim of citizens is to reach public services due to their basic needs, while the disaster response teams' aim is to reach more people who need help (Sohn, 2006).

The site selection of urban land uses (gathering points, evacuation areas, temporary shelters) except roads is also critical in terms of the accessibility for citizens, survivors and disaster response teams (Erdem et al., 2017). At this point, the size of any functionalized area in the disaster management should be evaluated as the capacity which the population needs, while the site selection should be evaluated as the service area related the distance. In any case, certain areas that are adequate for the population with regards to the area size and capacity can be inadequate with respect the access distance. So, in the process of designing the needed areas in urban, basic necessities should be considered in the neighbourhood, region and city scale as well as the functions and special features of area like as population, the access distance for pedestrians and vehicles, etc.

The population and size of area affect the adequacy of gathering points. For the calculation of these points' adequacy is based on the essential area per person after the disaster. At this point, the time spent in these areas becomes important. In other words, the waiting period determines the behaviours of citizens. The behaviours of them are affected due to the level of damage, news from the media, the dimension of disaster, etc. (Song et al., 2014)

\section{DATA AND THE STUDY AREA}

The study area named Bayrakli district is located in the northwest part of Izmir metropolitan city which is one of the biggest cities of Turkey. The total settled area of Bayrakli district is 3499.3 ha $\left(34.99 \mathrm{~km}^{2}\right)$ and covers approximately $4.5 \%$ of Izmir city's total area (78806.6 ha). According to the population obtained from Turkish Statistical Institute, the total population of Izmir metropolitan city is $4.279,677$ people and also the total population of Bayrakli district is 314.402 people by the year 2017 (TSI, 2017). In the district, there exist residential areas in differing densities and social profiles, commercial areas, open and green areas, archaeological areas (Bayrakli Mound, remains from Smyrna Ancient City, Tantalos's Tumulus), the coastline with recreational areas and a regional railway station. The district's location is represented in Figure 1.

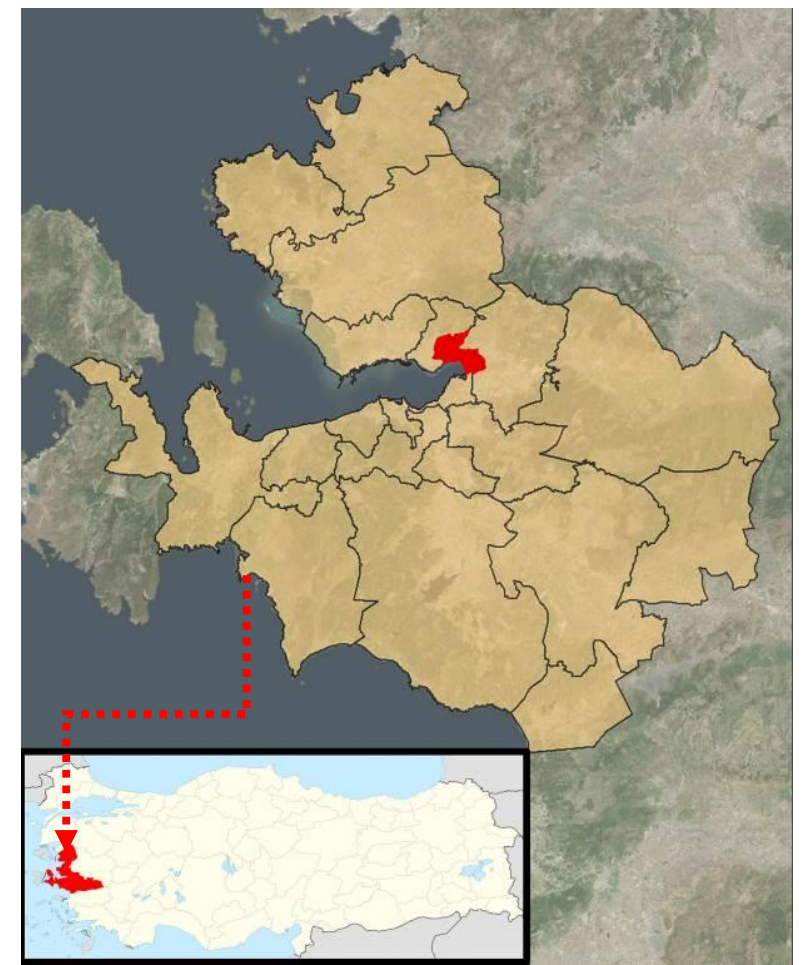

Figure 1. The location of Izmir metropolitan city and study area

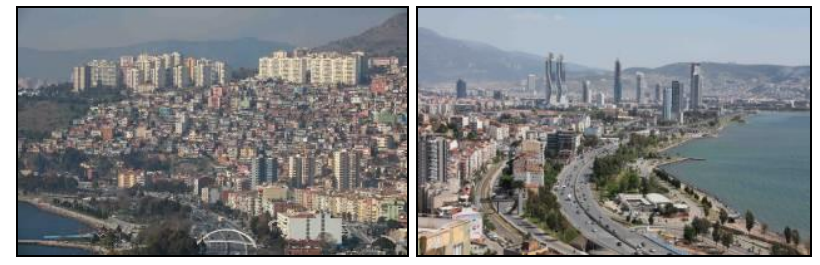

Figure 2. The current urban land pattern and the spatial relation with the coastline (Bayrakli Municipality, 2018)

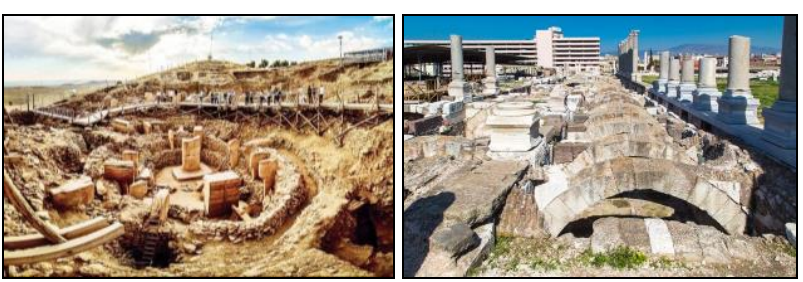

Figure 3. The Bayrakli Mound and remains from Smyrna Ancient City (Ministry of Culture and Tourism, 2018) 
There exist 23 neighbourhoods in Bayrakli district which differ from each other in terms of urban pattern characteristics and population. In these neighbourhoods, the land use patterns varies such as residential areas for lower and upper income levels, business and administrative centres, urban renewal areas, green areas in urban and district scale and also gathering points that can be used during and after the disaster (Figure 2). Figure 4 represents the locations of neighbourhoods in Bayrakli district and Figure 5 represents the transportation network with road classification. Also Table 1 shows the detailed information about physical characteristics of district's neighbourhoods.

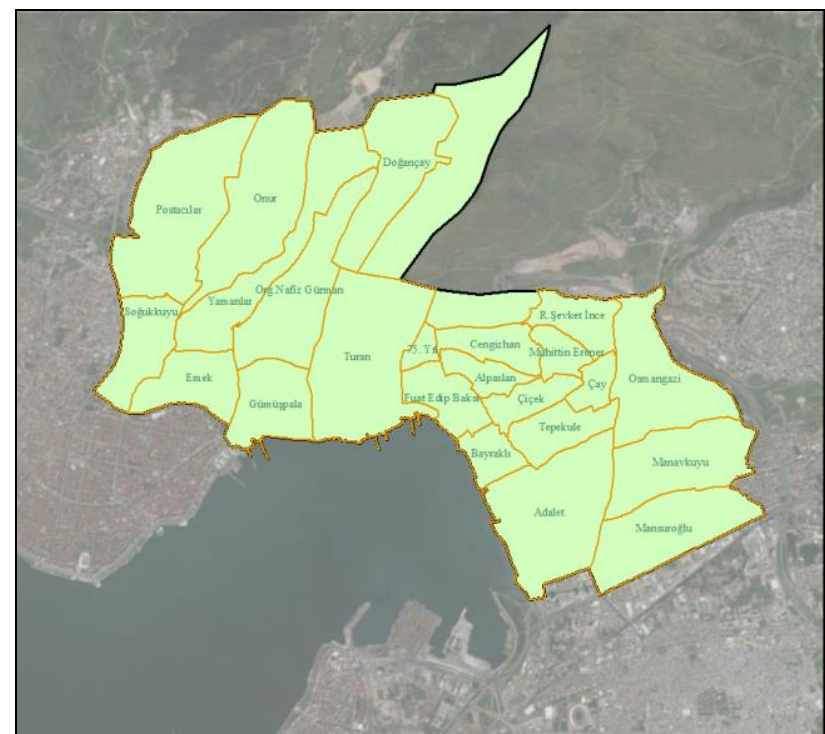

Figure 4. The locations of neighbourhoods in Bayrakli district

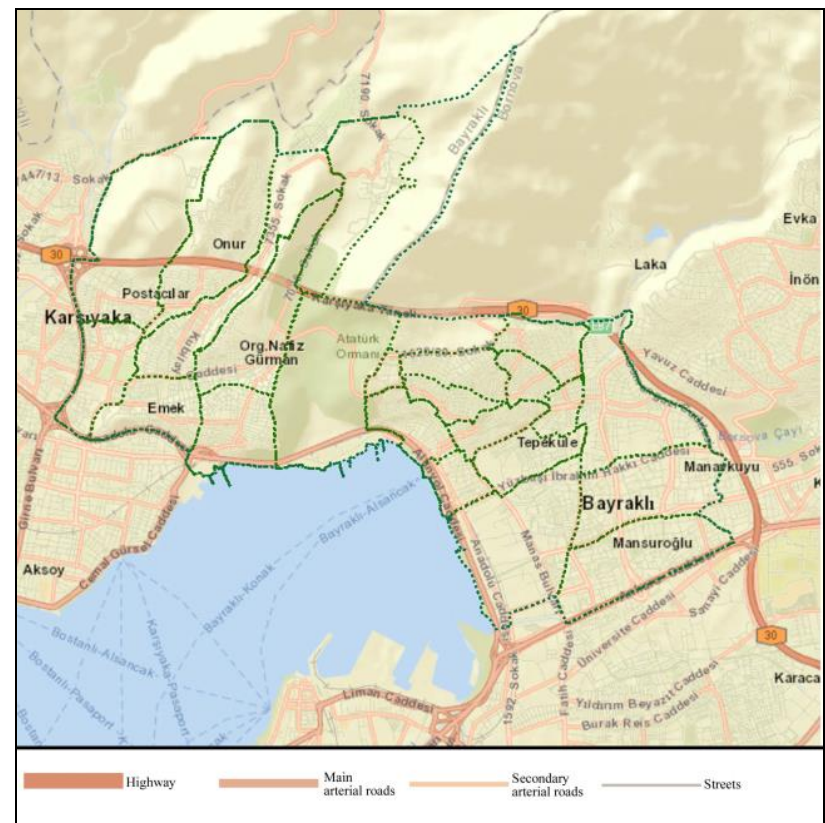

Figure 5. Current transportation network of the district

In terms of transportation routes of Bayrakli district, main arterials that carry heavy traffic accumulations in urban centre are located near the district centre and also the coastline. This network shows that gathering points and temporary sheltering areas used during and after the disaster can be easily accessible in the shortest possible duration by automobiles and public service vehicles.

\begin{tabular}{|l|c|c|}
\hline Neighborhoods & $\begin{array}{c}\text { The Size of } \\
\text { Neighborhoods } \\
\text { (ha) }\end{array}$ & $\begin{array}{c}\text { The Percentage of } \\
\text { Neighborhoods' Sizes } \\
\text { in Bayrakli District } \\
(\%)\end{array}$ \\
\hline Adalet & 190.455 & 8,37 \\
\hline Mansuroglu & 135.392 & 5,95 \\
\hline Manavkuyu & 129.951 & 5,71 \\
\hline Bayrakli & 36.481 & 1,60 \\
\hline Tepekule & 58.755 & 2,58 \\
\hline Gumuspala & 84.964 & 3,73 \\
\hline Osmangazi & 146.764 & 6,45 \\
\hline Fuat Edip Baksi & 56.312 & 2,47 \\
\hline Cicek & 39.572 & 1,74 \\
\hline Cay & 25.929 & 1,14 \\
\hline Alparslan & 33.343 & 1,46 \\
\hline Emek & 74.960 & 3,29 \\
\hline Sogukkuyu & 76.448 & 3,36 \\
\hline Postacilar & 216.799 & 9,53 \\
\hline Yamanlar & 140.950 & 6,19 \\
\hline Onur & 180.702 & 7,94 \\
\hline Nafiz Gurman & 141.797 & 6,23 \\
\hline Turan & 221.580 & 9,74 \\
\hline Dogancay & 136.782 & 6,01 \\
\hline 75. Yil & 14.855 & 0,65 \\
\hline Cengizhan & 49.759 & 2,19 \\
\hline R.Sevket Ince & 52.919 & 2,32 \\
\hline Muhittin Erener & 29.912 & 1,31 \\
\hline & & \\
\hline
\end{tabular}

Table 1. Physical characteristics of neighbourhoods

Due to Table 1, certain neighbourhoods' sizes and percentages are more than the others such as Postacilar, Adalet, Onur and Turan. This size refers the spatial magnitude of any neighbourhood. But the parameter of size is merely inadequate to determine the capacity, accessibility and mobility of gathering points.

\section{METHOD AND MATERIALS}

The method of this study has 4 steps. In the first step, existing information for the quality and quantity of open and green areas as "potential gathering points" in the neighbourhood scale are obtained and updated. Therefore, a database is set including the populations of neighbourhoods for the year 2016, the types and size of open and green areas and the size of gathering points in Bayrakli district. In the second step, the capacity of any gathering areas in the neighbourhood scale is calculated using values obtained from empirical studies in the literature, the adequacy of these gathering areas are compared with current sizes of them and also a classification is made related this adequacy.

In the third step, certain neighbourhoods are selected in terms of their gathering points' adequacy and accumulation, a buffer zone for a defined area in each selected neighbourhood by taking minimum standards and some recommendations into consideration, another database is set for buildings (number of floors, number of households, population and capacity) in these buffer zones which can be easily access to this gathering points in the shortest duration. In the last step, the building blocks that can get services from the defined gathering point in the neighbourhood are determined, these points are examined in terms of accessibility, mobility and their capacity for each neighborhood due to their spatial distribution. 


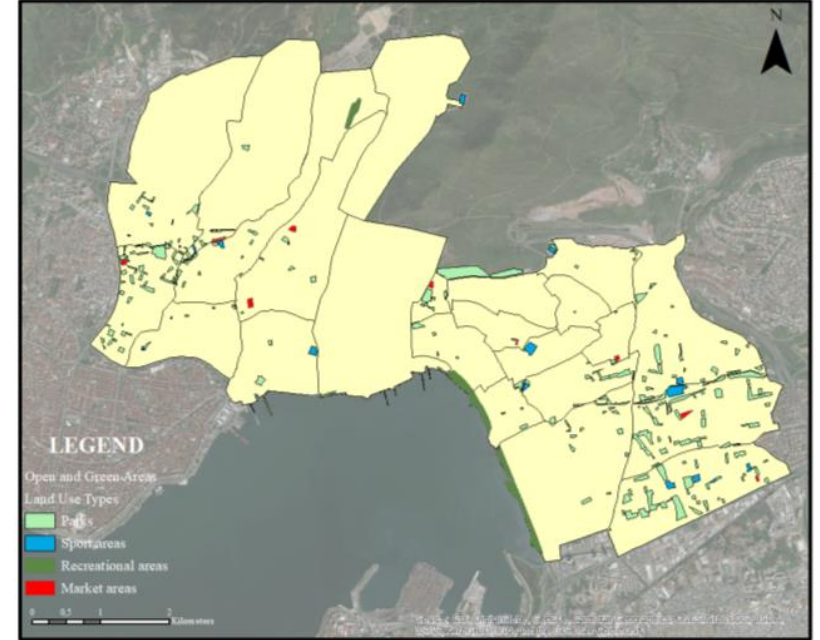

Figure 6 . The classification of gathering points

In this study, existing open and green areas in the neighbourhood scale are divided into 6 classes according to their characteristics such as parks, sport areas, recreation areas, cemeteries, squares and market places. This classification and locations of these areas are shown in Figure 6. According to Figure 6, parks, market places and sport areas from current open and green areas which can be determined as "potential gathering points" are accumulated in the west part (Sogukkuyu, Yamanlar, Postacilar, Onur and Nafiz Gurman neighbourhoods) and south-east part (Osmangazi, Manavkuyu, Mansuroglu and Tepekule neighbourhoods) of the district. Moreover, recreational areas are located generally in the coastline (Figure 6).

\begin{tabular}{|l|c|c|c|}
\hline Neighborhoods & $\begin{array}{c}\text { Population } \\
(2016)\end{array}$ & $\begin{array}{c}\text { Current Size of } \\
\text { Gathering } \\
\text { Points }\left(\mathrm{m}^{2}\right)\end{array}$ & $\begin{array}{c}\text { Capacity of } \\
\text { Gathering } \\
\text { Points }\left(\mathrm{m}^{2}\right)\end{array}$ \\
\hline Adalet & 20.471 & 127.848 & 51.177 \\
\hline Mansuroglu & 26.293 & 158.505 & 65.732 \\
\hline Manavkuyu & 31.821 & 167.393 & 79.552 \\
\hline Bayrakli & 6.697 & 37.919 & 16.742 \\
\hline Tepekule & 15.739 & 36.014 & 39.347 \\
\hline Gumuspala & 15.423 & 18.486 & 38.557 \\
\hline Osmangazi & 26.678 & 62.575 & 66.695 \\
\hline F. Edip Baksi & 12.337 & 38.667 & 30.842 \\
\hline Cicek & 9.988 & 18.014 & 24.970 \\
\hline Cay & 7.763 & 4.789 & 19.407 \\
\hline Alparslan & 8.929 & 2.542 & 22.322 \\
\hline Emek & 12.785 & 5.870 & 31.962 \\
\hline Sogukkuyu & 11.440 & 87.546 & 28.600 \\
\hline Postacilar & 13.348 & 25.793 & 33.370 \\
\hline Yamanlar & 17.978 & 43.251 & 44.945 \\
\hline Onur & 20.154 & 20.196 & 50.385 \\
\hline Nafiz Gurman & 15.787 & 21.264 & 39.467 \\
\hline Turan & 347 & 19.839 & 867 \\
\hline Dogancay & 2.236 & 5.889 & 5.590 \\
\hline 75.Yil & 3.471 & 22.114 & 8.677 \\
\hline Cengizhan & 13.357 & 0 & 33.392 \\
\hline R.Sevket Ince & 12.436 & 3.470 & 31.090 \\
\hline Muhit. Erener & 8.530 & 333 & 21.325 \\
\hline & & & \\
\hline
\end{tabular}

Table 2. The size and capacity of gathering points Then, a database is set including certain details related neighbourhoods such as population, the types and size of open and green areas and the size of gathering points in the district.
In terms of population and gathering points' sizes, there exists an accumulation in Manavkuyu, Adalet, Mansuroglu and Sogukkuyu neighbourhoods (Table 2). As the parameter of size, the population parameter is not just adequate to determine the capacity, accessibility and mobility of gathering point.

As a second step, the capacity of gathering areas in the district can be calculated based on that the essential area per person after the disaster is generally between $1-2.5 \mathrm{~m}^{2}$ in literature (Atalay, 2008). In this study, this area is selected as $2.5 \mathrm{~m}^{2}$. For example, the population of Adalet neighbourhood is 20.471 and the essential area of gathering points for this neighbourhood should be $51.177 \mathrm{~m}^{2}$ (20.471 people*2.5 person $\left./ \mathrm{m}^{2}\right)$. After this calculation, the adequacy of these gathering areas are compared with current sizes of them and also a classification is made related this adequacy into two classes such as "adequate" or "not adequate". According to this, there exist only 9 neighbourhoods that have enough gathering points for citizens settled in these neighbourhoods (Table 3 and Figure 7).

\begin{tabular}{|l|c|c|}
\hline Neighborhoods & $\begin{array}{c}\text { Capacity of } \\
\text { Gathering Points }\left(\mathrm{m}^{2}\right)\end{array}$ & $\begin{array}{c}\text { Adequacy of } \\
\text { Gathering Points }\end{array}$ \\
\hline Adalet & 51.177 & Adequate \\
\hline Mansuroglu & 65.732 & Adequate \\
\hline Manavkuyu & 79.552 & Adequate \\
\hline Bayrakli & 16.742 & Adequate \\
\hline Tepekule & 39.347 & Not adequate \\
\hline Gumuspala & 38.557 & Not adequate \\
\hline Osmangazi & 66.695 & Not adequate \\
\hline F. Edip Baksi & 30.842 & Adequate \\
\hline Cicek & 24.970 & Not adequate \\
\hline Cay & 19.407 & Not adequate \\
\hline Alparslan & 22.322 & Not adequate \\
\hline Emek & 31.962 & Not adequate \\
\hline Sogukkuyu & 28.600 & Adequate \\
\hline Postac1lar & 33.370 & Not adequate \\
\hline Yamanlar & 44.945 & Not adequate \\
\hline Onur & 50.385 & Not adequate \\
\hline Nafiz Gurman & 39.467 & Not adequate \\
\hline Turan & 867 & Adequate \\
\hline Dogancay & 5.590 & Adequate \\
\hline 75. Yil & 8.677 & Adequate \\
\hline Cengizhan & 33.392 & Not adequate \\
\hline R.Sevket Ince & 31.090 & Not adequate \\
\hline Muhit. Erener & 21.325 & Not adequate \\
\hline
\end{tabular}

Table 3 . The adequacy of gathering points' capacities

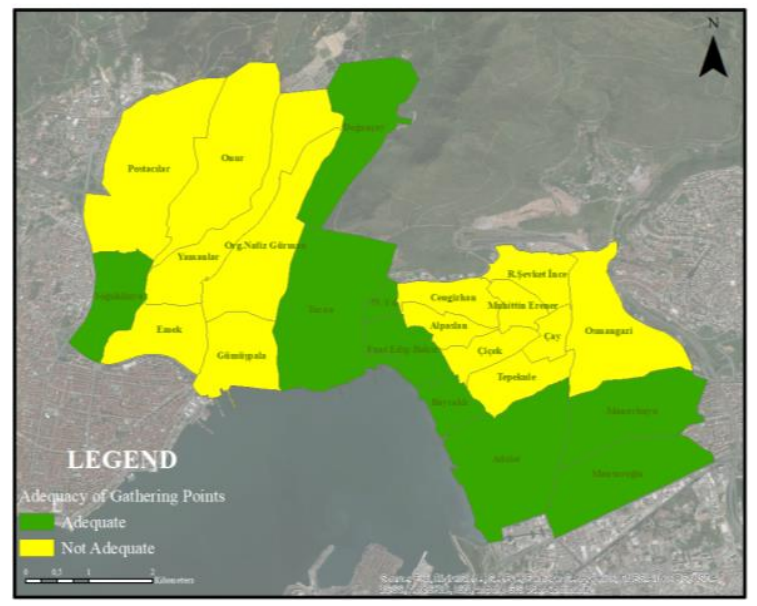

Figure 7. The adequacy of gathering points in neighbourhood 


\begin{tabular}{|l|c|c|}
\hline Neighborhoods & $\begin{array}{c}\text { Adequacy of } \\
\text { Gathering Points }\end{array}$ & $\begin{array}{c}\text { Density of } \\
\text { Gathering Points }\end{array}$ \\
\hline Adalet & Adequate & Dense \\
\hline Mansuroglu & Adequate & More dense \\
\hline Manavkuyu & Adequate & More dense \\
\hline Bayrakli & Adequate & Less dense \\
\hline F. Edip Baksi & Adequate & Less dense \\
\hline Sogukkuyu & Adequate & More dense \\
\hline Turan & Adequate & Less dense \\
\hline Dogancay & Adequate & Less dense \\
\hline 75.Yil & Adequate & Dense \\
\hline
\end{tabular}

Table 4 . The density of gathering points

In another step as the third step includes firstly certain neighbourhoods are selected in terms of their gathering points' adequacy and accumulation. According to the data obtained from Table 3, Table 4 and Figure 6, two neighbourhoods named Sogukkuyu and Fuat Edip Baksi are selected to examine the capacity and the accessibility of gathering points due to the population parameter. The principal reasons of this selection can be listed as the accumulation of gathering points in these neighbourhoods comparing to other ones and being adequate in terms of capacity. There exist some significant differences in these neighbourhoods such as the buildings' density, the level of gathering points' density, social and economic profiles. Figure 8 shows the locations of these neighbourhoods and Figure 9 shows the locations of selected gathering points.

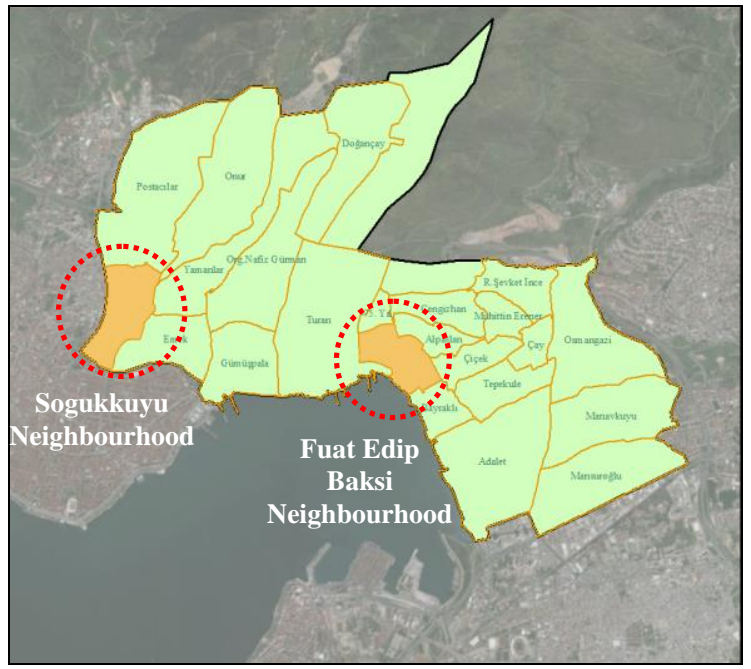

Figure 8. The selected neighbourhoods

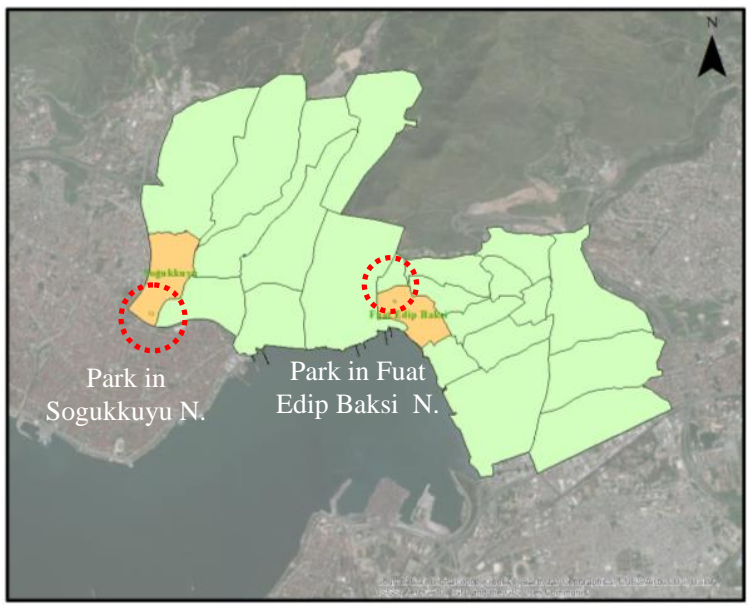

Figure 9. The selected gathering points
Then, buffer zones are made for these two selected points by taking minimum standards and some recommendations into consideration, another database is set for buildings (number of floors, number of households, population and capacity) in these buffer zones which can be easily access to this gathering points in the shortest duration. These zones' radius is 200 meters. This value is determined in the study based on that the shortest possible walking distance during and after the disaster in literature (Tarabanis and Tsionas, 1999; OASP, 2002; Atalay, 2008).

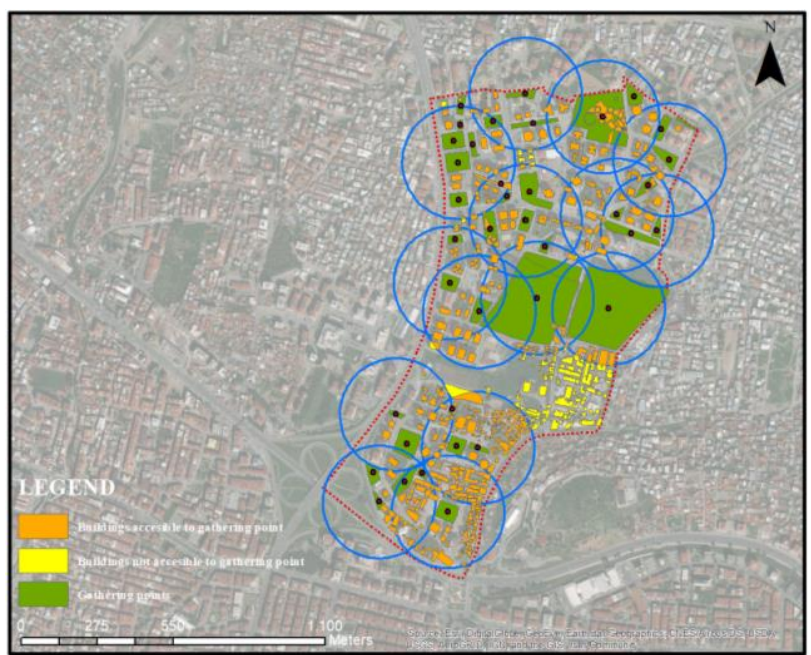

Figure 10. The accessibility of gathering points in Sogukkuyu

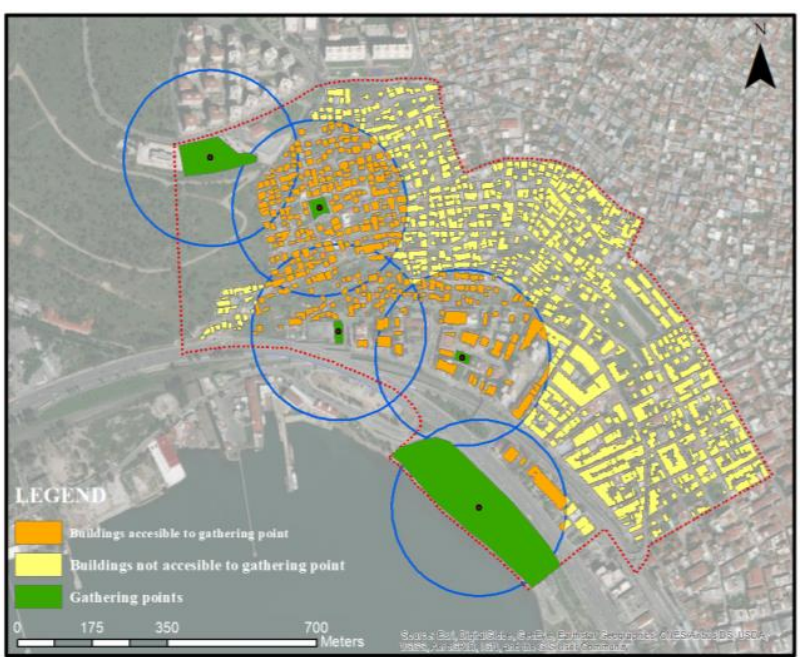

Figure 11. The accessibility of gathering points in Edip Baksi

In Figure 10, it can be easily seen that almost whole buildings can access to the gathering points in Sogukkuyu neighbourhood except the ones located in south-east part of the neighbourhood. In comparison to this, In Figure 11, the better part of buildings in Fuat Edip Baksi neighbourhood cannot access to the gathering points especially in the north and east parts of the neighbourhood. On the other hand, buildings located in the west and south parts of the neighbourhood can easily access to these points. Due to the spatial analyses, the population that can get services from any gathering points in Sogukkuyu neighbourhood is 9680 people and the percentage of this population is approximately $85 \%$ in proportion to whole neighbourhood. Also, the population that cannot get services is 1760 people and the percentage of this population is approximately 15\% in Sogukkuyu neighbourhood. In Fuat Edip 
Baksi neighbourhood, 7140 people can get services from any gathering points and the percentage of this population is approximately 59\%, but 5197 people cannot get any services and the percentage of this population is approximately $41 \%$ in proportion to whole neighbourhood.

For the last step, the buildings which can get services from the selected gathering points in two neighbourhoods are determined. Moreover, the population, current size of selected gathering point and also the needed capacity for population are calculated via the ArcMap software. According to the results of spatial and numerical analyses, in Sogukkuyu neighbourhood, the total population of area is 2808 people and the size of the selected gathering points is measured as $2803 \mathrm{~m}^{2}$. The needed capacity for total population is $7020 \mathrm{~m}^{2}$. So, this point is definitely inadequate for citizens settled during and after the disaster (Figure 12). In Fuat Edip Baksi neighbourhood, the total population of area is 2716 people and the size of the selected gathering points is measured as $968 \mathrm{~m}^{2}$. The needed capacity for total population is $6790 \mathrm{~m}^{2}$. So, this point is definitely inadequate for citizens settled during and after the disaster as the situation in Sogukkuyu neighbourhood. (Figure 13). Figure 12 and 13 represent these buffer zones and also building blocks included with these zones according to their land use types in Sogukkuyu and Fuat Edip Baksi neighbourhoods.

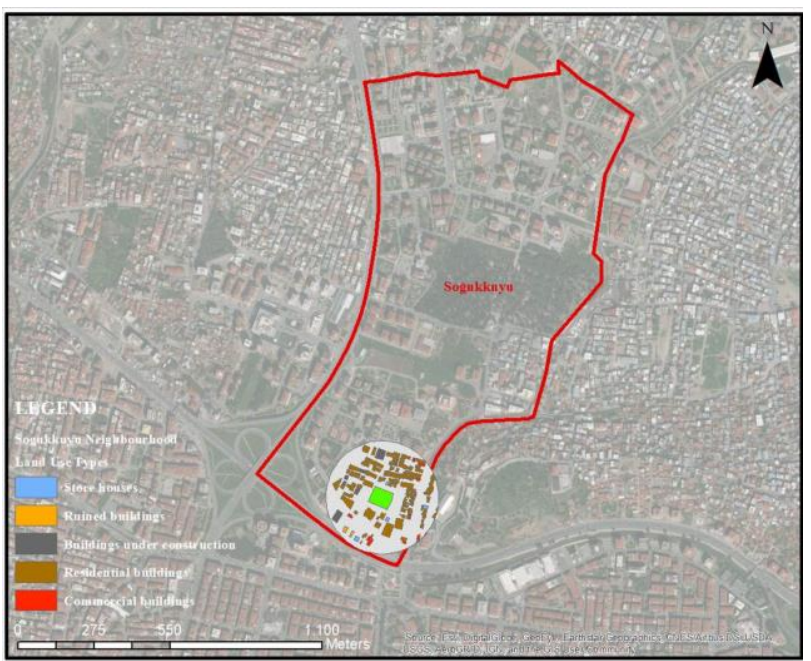

Figure 12. The selected point and buildings in Sogukkuyu

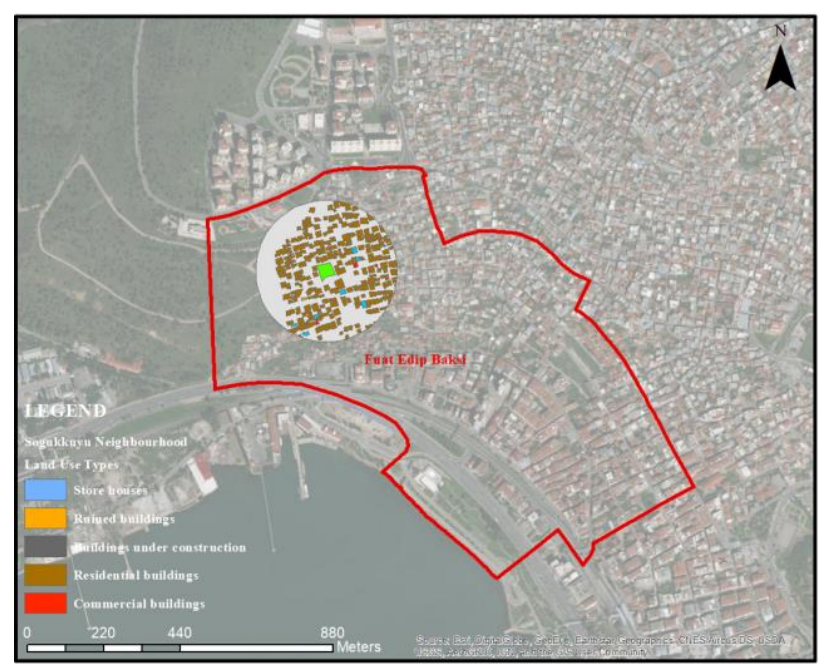

Figure 13. The selected point and buildings in Edip Baksi

\section{RESULTS AND DISCUSSION}

The aim of this study is to examine the accessibility of selected gathering points regarding their capacities and mobilities by taking minimum standards into consideration in Bayrakli district. Thus, a four-phased method is carried out. In these phases, there exist updating obtained data for open and green areas as "potential gathering points", setting a database for them with various data of neighbourhoods, determining the adequacy of these areas after calculations, define a diameter for walking distance in the shortest duration, examining the conditions of neighbourhoods and buildings in buffer zones in terms of adequacy, capacity, mobility and getting services from certain gathering points.

According to spatial analyses carried out via ArcMap software, there exist only 9 neighbourhoods that have enough gathering points for current populations among 23 neighbourhoods in Bayrakli district. The "adequate" neighbourhoods are generally located in the east and south parts, while "inadequate" neighbourhoods are located in west and north parts of the district. Moreover, three of these "adequate" neighbourhoods have "more dense" gathering areas, two of them have "dense" gathering areas and also four of them have "less dense" gathering areas. There is no accumulation of these areas throughout the district. While the selected two neighbourhoods (Sogukkuyu and Fuat Edip Baksi neighbourhoods) are determined as "adequate" neighbourhoods due to the size and population parameters, but there exist still certain areas which cannot get services from any gathering points in these neighbourhoods. The percentage of population that can get services from any gathering points is approximately $15 \%$ in Sogukkuyu neighbourhood and $41 \%$ in Fuat Edip Baksi neighbourhood in proportion to whole neighbourhood (Figure 10 and 11). It is determined that the percentage of current gathering point's size in proportion to the needed size is approximately $40 \%$ in the selected area located in Sogukkuyu neighbourhood and also is approximately $14 \%$ in the selected area located in Fuat Edip Baksi neighbourhood (Figure 12 and 13).

It is definitely clear that the parameters of size and population cannot merely determine the capacity, accessibility and mobility of any gathering points in an urban area. As mentioned before, certain gathering areas can be inadequate with respect the access distance which these areas are adequate for the population with regards to the area size and capacity in any case. For example, Sogukkuyu neighbourhood is easily accessible because of its location which is closer to main arterial roads, the district centre, coastline and also many gathering points are located around the neighbourhood. Although citizens settled in certain areas and buildings cannot get services from these gathering points in an event of disaster. In other words, these areas and buildings cannot be easily access to these gathering points in the shortest duration by walking.

These analyses' results are so crucial for urban areas. Because they help us understand the inadequacy of evaluations using limited parameters (size and population) related gathering points in any urban area. In fact, various criteria affect the site selection of gathering points for getting services in the event of disaster. The appropriate and specific ones for any case should be selected if the capacity of these areas is examined regarding mobility and accessibility. 


\section{ACKNOWLEDGEMENTS}

This research is based upon work supported by the Disaster and Emergency Management Authority (AFAD) of the Prime Ministry under Grant No: UDAP-G-16-08. This work would not have been possible without the financial support of AFAD.

\section{REFERENCES}

Atalay, H., 2008. Deprem Durumunda Kentsel Açik ve Yeşil Alanlarin Kullanimi - Küçükçekmece Cennet Mahallesi Örneği, Master Thesis, Istanbul Technical University, Istanbul.

Chang, S.E., 2003. Transportation planning for disasters: an accessibility approach. Environment and Planning A, 35(6), pp. 1051-1072.

Earthquake Planning and Protection Organization (OASP), 2002. Emergency evacuation of the population in case of an earthquake, Handbook No:3, Athens, Greece.

Erdem, U., Erdin H. E., Özcan N. S., 2017. Afet ve Acil Durumlarda Erişilebilirlik, 4. Uluslararası Deprem Mühendisliği ve Sismoloji Konferansı (UDMSK), Eskişehir. http://www.tdmd.org.tr/TR/Genel/4UDMSK/pdf2017/3887.pdf.

Erdin H. E., Zengin Çelik H., Sılaydın Aydın M. B., Özcan N. S., Erdem, U., 2017. Afet yönetimi içerisinde kentsel mekan ihtiyacı ve kentsel arazi kullanımları, Disiplinlerarası Afet Yönetimi Araştırmaları, Editörler: Zerrin Toprak Karaman, Oğuz Sancakdar, İlkim Kaya, Albi Yayınları, Izmir, pp: 255272.

Konstantinidou, M., Kepaptsoglou, K., ve Karlaftis, M., 2014. Transportation network post-disaster planning and management: a review part I: post-disaster transportation network performance. International journal of transportation, 2(3), pp. 1-16.

Liu, L., Lin, Y., Wang, S., 2014. Urban design for postearthquake reconstruction: A case study of Wenchuan County, China. Habitat International, 41, pp. 290-299.

Maral, H., Akgün, Y., Çınar, A.K., Karaveli, A.S., 2015. İzmir'deki afet sonrası toplanma ve acil barınam alanları üzerine bir değerlendirme. 3. Türkiye Deprem Mühendisliği ve Sismoloji Konferansı, Izmir, Turkey.

Ministry of Culture and Tourism, 2018. Official web site of Ministry. http://www.kultur.gov.tr/

Municipality of Bayrakli, 2018. Official web site of Municipality. http://www.bayrakli.bel.tr/

Sohn, J., 2006. Evaluating the significance of highway network links under the flood damage: An accessibility approach. Transportation research part A: policy and practice, 40(6), pp. 491-506.

Song, X., Zhang, Q., Sekimoto, Y., Shibasaki, R., 2014. Prediction of human emergency behaviour and their mobility following large-scale disaster, New York, USA. http://dx.doi.org/10.1145/2623330.2623628.
Tarabanis, K and Tsionas, I., 1999. Using network analysis for emergency planning in case of an earthquake. Transactions in GIS, 3(2), pp.187-197.

Turkish Statistical Institute, 2017. Population of neighbourhoods in Bayrakli district. 